\title{
PENGGUNAAN STRATEGI PEMBELAJARAN COOPERATIF LEARNING UNTUK MENINGKATKAN HASIL BELAJAR METODE PEKERJAAN SOSIAL JAKARTA
}

\author{
Nunuk Sri Murbaetty \\ SMKN 28 Jakarta \\ murbaettynunuk@yahoo.co.id
}

\begin{abstract}
Abstrak
Artikel ini memberikan pemaparan tentang upaya meningkatkan hasil siswa melalui belajar metode cooperatif learning dalam meningkatkan sikap sosial peserta didik. Penelitian ini adalah penelitian tindakan kelas yang dilakukan dengan dua silkus yang terdiri dari tahap perencanaan, pelaksanaan, observasi atau evaluasi dan refleksi yang dilakukan disetiap silkus. Secara psikologis peserta didik di kelas XI PS2 adalah anak yang telah masuk masa pubertas atau dari masa anak-anak ke masa dewasa oleh karena itu mereka harus bisa menganalisis dan memandang terhadap sesuatu itu menyeluruh dengan penghayatan secara totalitas. Atas dasar itulah, sehingga kegiatan pembelajaran yang sesuai untuk mereka adalah model pembelajaran dengan pendekatan cooperatif learning, dan suasana pembelajarannya pun diciptakan yang menyenangkan. Sehubungan dengan model pembelajaran dengan pendekatan cooperatif learning merupakan strategi pembelajaran yang lebih banyak melibatkan peserta didik dalam menggali materi harus mandiri, karena teman sebaya merupakan nara sumber untuk peserta didik lainnya, maka tujuan penelitian ini untuk mengetahui dan mengukur sejauh mana efektifitas konsep pembelajaran dengan pendekatan cooperatif learningitu dapat memotivasi belajar peserta didik untuk kreatif yang berdampak kepada hasil belajar yang optimal. Pelaksanaan penelitian tindakan kelas ini mengikuti prosedur yang di mulai dari tahap perencanaan, pelaksanaan/tindakan pengamatan, observasi atau evaluasi dan diakhiri dengan refleksi guna menentukan dilanjutkan atau sudah cukup tindakan penelitian itu. Dilihat dari hasil analisa data, bahwa dari silkus satu ke siklus berikutnya yaitu sikus dua menunjukan hasil yang terus menerus meningkat.
\end{abstract}

Kata-kata kunci: metode cooperatif learning, psikologi peserta didik, sikap sosial, pekerjaan sosial

\footnotetext{
Jurnal Pendidikan Kewarganegaraan

Journal of Civics and Education Studies

The journal is published by Department of Civic Education

Faculty of Teacher Training and Education

Universitas Pamulang - Indonesia

Copyright $\odot$ 2017|ISSN: 2302-0865
} 


\section{PENDAHULUAN}

Proses belajar mengajar merupakan suatu proses yang mengandung serangkaian perbuatan guru dan peserta didik atas dasar hubungan timbal balik yang langsung dalam situasi educative untuk mencapai tujuan tertentu. Interaksi atau hubungan timbal balik antara guru dan peserta didik itu merupakan syarat utama bagi berlangsungnya proses belajar mengajar.Interaksi dalam peristiwa belajar mengajar mempunyai arti yang lebih luas, tidak sekedar hanya hubungan antara guru dan peserta didik, tetapi berupa interaksi edukatif.Amos Kandola (2006), pembelajaran kooperatif merupakan suatu model pembelajaran di mana siswa belajar dalam kelompok- kelompok kecil yang memiliki tingkat kemampuan berbeda, dalam menyelesaikan tugas kelompok setiap anggota saling bekerjasama dan membantu untuk memahami suatu bahan pembelajaran. Belajar belum selesai jika salah satu teman dalam kelompok belum menguasi bahan pembelajaran.

Metode Pekerjaan Sosial mengarah pada pembentukan ketrampilan (vokasi) yang diharapkan diwujudkan dalam perilaku sehari-hari, melalui metode pekerjaan sosial para peserta didik diharapkan mampu mengembangkan potensinya baik sebagai pribadi, anggota masyarakat, bangsa

dan Negara.Disamping itu melalui metode pekerjaan sosial peserta didik juga dibekali pengetahuan dan kemampuan dasar serta ketrampilan pekerjaan sosial yang berkenan dengan hubungan antar pekerjaan sosial dengan klien ataupun sebagai penghubung untuk merujuk penanganan masalah perorangan, kelompok, ataupun masyarakat . Dengan demikian diharapkan metode pekerjaan sosial tidak menimbulkan kebosanan oleh karena itu kepada setiap guru diharapkan dapat mengajarkan metode pekerjaan sosial ini dengan model pembelajaran yang menyenangkan dan dapat memotivasi peserta didik untuk trampil dalam penangan kasus dalam kehidupan perorangan, kelompok ataupu masyarakat.

Menurut Tabrani Rusyan dalam mendifinisikan proses belajar mengajar berpendapat bahwa proses belajar mengajar, adalah suatu proses melihat dan mengalami, mengamati dan memahami melalui pembinaan, pemberian penjelasan, pemberian bantuan dan dorongan dari pendidik.Dari pengertian di atas dapat dikatakan bahwa proses belajar mengajar merupakan suatu kegiatan yang tidak terpisahkan antara guru sebagai pengajar dengan peserta didik sebagai pelajar dalam mencapai tujuan edukatif.

Berdasarkan observasi awal di lapangan tingkat pemahaman terhadap materi yang disajikan oleh guru terhadap peserta didik salah satu SMK Negeri yang ada di Jakarta pada tahun pelajaran tahun 2016 mengalami penurunan. Hal ini menurut pengamatan penulis disebabkan oleh pendekatan dan strategi yang kurang tepat diterapkan sehingga motivasi belajar rendah, dengan hasil belajar peserta didik berada di bawah kriteria ketuntasan minimal (KKM) yakni 75.Penulis menduga penerapan strategi pembelajaran perlu dirubah menjadi 
strategi yang menarik bagi peserta didik yakni cooperative learning. Cooperatif learning (pembelajaran kooperatif) berbeda dengan metode diskusi yang biasanya dilaksanakan di kelas, karena pembelajaran kooperatif menekankan pembelajaran dalam kelompok kecil di mana peserta didik belajar dan bekerjasama untuk mencpai tujuan yang optimal. Pembelajaran koopertif meletakkan tanggung jawab individu sekaligus kelompok, sehingga diri peserta didik tumbuh dan berkembang sikap, perilaku saling ketergantungan secara positif.Kondisi ini dapat mendorong siswa untuk belajar, bekerja dan bertanggung jawab secara sungguh-sungguh untuk mencapai tujuan yang telah ditetapkan.

\section{METODE PENELITIAN}

Rancangan prosedur penelitian tindakan kelas yang dilaksanakan dalam penelitian ini adalah model pembelajaran spiral atau siklus, menurut Stephen Kemmis dan MC, Taggaret.Dengan ditemukan adanya kekurangan, maka perencanaan dan pelaksanaan perbaikan masih dapat pada siklus berikutnya sampai target yang diinginkan tercapai.

Rancangan model Kemmis memiliki empat tahapan pada setiap siklusnya, yaitu: a) pembuat rencana tindakkan; b) melaksanakan tindakkan; c) mengadakan pengamatan atau observasi; dan d) mengadakan refleksi dan evaluasi.

Penelitian ini dilihat dari aspek kedekatan metodologi menggunakan metodelogi penelitian tindakan kelas (PTK). Data yang terkumpul di analisis dengan menggunakan nilai kuantitatif dan kualitatif .Untuk nilai kualitatif dilakukan dengan mendiskripsikan hasil pengamatan selama tindakan berlansung. Sedangkan untuk nilai kuantitative menunjuk pada buku laporan pendidikan yang menunjukan pada buku laporan pendidikan yang ditetapkan dalam satuan pendidikan sebagaiberikut:
a. Nilai 90 - 100 sangat baik
b. Nilai $79-89$ baik
c. Nilai $70-78$ cukup
d. Nilai 59-69 kurang
e. Nilai $40-58$ sangat kurang

\section{Penelitian Siklus I:}

\section{Tahap Perencanaan}

Penelitian ini dilaksanakan di kelas XI PS2 semester genap tahun 2016 di SMK Negeri 28 Kec. Cilandak, Jakarta Selatan. Pada siklus 1 (pertama) dirancang untuk meneliti proses belajar metode pekerjaan sosial dengan materi pembelajaran atau standar kompetensi case studi yang dilaksanakan dalam 2 kali pertemuan. Perencanaan kegiatan pembelajaran telah dirumuskan dalam RPP.Untuk materi ini menggunakan strategi metode cooperative learning (pembelajaran kooperatif). Pembelajaran kooperatif mengupayakan peserta didik mampu mengajarkan kepada peserta lain. Mengajar teman sebaya memberikan kesempatan pada peserta didik untuk mempelajari sesuatu dengan baik dalam waktu yang bersamaan, ia menjadi nara sumber bagi teman yang lainnya. Pengorganisasian pembelajaran dicirikan siswa yang bekerja dalam situasi pembelajaran kooperatif didorong untuk 
bekerjasama pada suatu tugas bersama, dan mereka harus mengkoordinasikan usahanya untuk menyelesaikan tugasnya. Mereka akan berbagi penghargaan bila mereka berhasil sebagai kelompok.

\section{Tahap Pelaksanaan}

Kegiatan siklus I (pertama) pada pertemuan pertama dilaksanakan pada hari kamis, 6 september 2016, sebanyak 2 jam pelajaran ( $2 \times 45$ menit) dimulai dari pukul $8.00 \mathrm{~s} / \mathrm{d}$ pukul 9.30. Kegiatan ini diawali dengan pengarahan guru dan menjelaskan bahwa hari ini standar kompetensi yang dibahas case studi kasus perorangan. Guru membagi 6 kelompok yang beranggotakan 5 orang, masingmasing kelompok di beri nama kelompok yaitu kelompok satu, kelompok dua, kelompok tiga, kelompok empat, kelompok lima, kelompok enam.Peserta didik di bagi dalam 6 kelompok, tiap kelompok kecil terdiri dari 5 orang jumlah peserta didik di kelas XI PS2 berjumlah 30 orang.

\section{Langkah-langkah pembelajaran}

1. Kegiatan awal

\section{a. Apersepsi}

1) Tanya jawab tentang pelajaran yang lalu

2) Menyampaikan pokok materi pembahasaan hari ini

3) Menginformasikan kompetensi dasar yang ingin dicapai dalam pembelajaran
4) Pembagian kelompok dan tugas masing-masing kelompok sebagai berikut:

a) Guru menyampaikan tugas-tugas yang harus dikerjakan masingmasing anggota kelompok yang berbeda, tugas tersebut adalah;

(1) kelompok 1 : metode bimbingan perorangan

(2) kelompok 2 : sistimatika case studi

(3) kelompok 3 : rencana dan pelaksanaan intervensi

(4) kelompok 4 : kasus bolos sekolah

(5) kelompok 5 : relasi dalam kasus bolos sekolah

(6) kelompok 6 : peranan pekerja sosial

2. Kegiatan inti

a. Eksplorasi

1) Secara bersamaan setiap kelompok mencari informasi dari buku metode pekerjaan sosial dan sumber lain yang relevan sesuai tugas masing-masing.

2) Setiap kelompok mengolah informasi dengan cara mendiskusikan dengan kelompoknya.

3) Setiap kelompok menganalisis informasi dan menghubungkan dengan kelompoknya. 
4) Setiap kelompok menyusun laporan diskusi secara tertulis untuk dipresentasikan.

b. Konsolidasi pembelajaran

1) Perwakilan kelompok mempresentasikan hasil diskusinya, dan kelompok lain memperhatikan dan memberi tanggapan.

2) Guru pengajar memfasilitasi dengan memberikan pelurusan dan klarifikasijika terjadi kesalahan konsep.

3) Guru kolaborator terus mengawasi antusias dan aktifitas siswa selama proses pembelajaran berlangsung

3. Kegiatan akhir
a. Guru pengajar mengklarifikasi ditiap kelompok bila terjadi kesalahan konsep dan melakukan pelurusan konsep
b. Mengambil kesimpulan secara bersama-sama

c. Evaluasi lisan dengan tanya jawab

d. Guru kolaborator terus mengawasi antusias dan aktivitas siswa selama proses pembelajaran berlangsung.

Peserta didik di bagi dalam 6 kelompok, tiap kelompok kecil terdiri dari 5 orang jumlah peserta didik di kelas XI PS2 berjumlah 30 orang.

\section{Hasil Pengamatan \\ Berdasarkan hasil pengamatan} guru kolaborator, bahwa belum maksimalnya hasil proses pembelajaran metode pekerjaan sosial pada siklus I diperoleh informasi dengan data sebagai berikut : Hasil evaluasi siklus I dapat di lihat pada tabel 1 . 
Tabel 1

Prestasi Hasil Belajar Metode Pekejaan Sosial Siklus I

\begin{tabular}{|c|c|c|c|c|c|}
\hline No & Katagori & Jumlah & Presentasi & Ketuntasan & Keterangan \\
\hline 1 & Sangat baik & 0 & $0 \%$ & \multirow{3}{*}{$\begin{array}{l}21 \text { orang siswa } \\
\text { sudah tuntas }\end{array}$} & \multirow{6}{*}{$\begin{array}{l}\text { Baru mencapai target } \\
\text { minimal yaitu 70\% } \\
\text { lanjut ke silkus dua }\end{array}$} \\
\hline 2 & Baik & 14 & $46.66 \%$ & & \\
\hline 3 & Cukup & 7 & $23.33 \%$ & & \\
\hline 4 & Kurang & 6 & $20 \%$ & 9 orang siswa & \\
\hline 5 & $\begin{array}{l}\text { sangat } \\
\text { kurang }\end{array}$ & 3 & $10 \%$ & belum tuntas & \\
\hline & Jumlah & \multicolumn{2}{|c|}{30 siswa } & $99.99 \%$ & \\
\hline
\end{tabular}

Dari hasil nilai tersebut ternyata masih ada 9 peserta didik yang belum memenuhi kriteria nilai standar kompetensi untuk pelajaran metode pekerjaan sosial yaitu 75. Selanjutnya berdasarkan hasil nilai ini, ketuntasan belajar peserta didik dalam mata pelajaran Metode Pekerjaan Sosial telah mencapai kriteria ketuntasan minimal (KKM) yang telah ditentukan yaitu 75.Dengan nilai sangat baik tidak ada peserta didik yang mendapatkannya nilai diperingkat tersebut, nilai baik diperoleh pada 14 peserta didik yang pencapaian nilainya yaitu 80 , sedang pencapaian nilai cukup yaitu 75 diperoleh 7 peserta didik, nilai kurang yaitu 59 dicapai oleh 6 peserta didik, dan nilai sangat kurang yaitu 50 dicapai oleh 3 peserta didik.

\section{Refleksi}

Berdasarkan hasil pengamatan guru kolaborator, bahwa belum maksimalnya hasil proses pembelajaran metode pekerjaan sosial pada siklus I diperoleh informasi dengan data sebagai berikut:

1. Kedisiplinan sebagian peserta didik dalam mengikuti proses pembelajaran masih kurang, keaktifannya cenderung bermainmain. Sehingga nilai kedisiplinan peserta didik rata-rata $76 \%$.

2. Keaktifan peserta didik dalam mengikuti proses pembelajaran 
yang cenderung main-main sehingga nilai rata-rata $74 \%$

3. Ketepatan waktu, peserta didik berusaha menyelesaikan pekerjaan, hasilnya rata-rata $78 \%$. Ini artinya kemampuan siswa untuk mengikuti pelajaran metode pekerjaan sosial masih rendah.

4. Interaksi peserta didik dengan guru dan sesamanya, seperti bertanya kepada guru, bertanya kepada teman, menjawab pertanyaan, menanggapi, mengerjakan tugas hasilnya rata-rata $70 \%$

Jadi disimpulkan bahwa materi pembelajaran metode pekerjaan sosial dengan standar kompetensi case studi kasus perorangan, perlu dilanjutkan ke silkus II dengan memperhatikan beberapa hal sebagai berikut :

1. Materi yang sudah dibagikan tetap digunakan

2. Memberi motivasi kepada peserta didik yang nilainya kurang dari 60

\section{Penelitian Siklus II}

\section{Tahap Perencanaan}

Penelitian ini dilakukan di SMK Negeri 28 Kec. Cilandak, Jakarta Selatan. Pada siklus 2 ini dirancang pembelajaran dengan materi case studi kasus perorangan, untuk 2 kali pertemuan.

\section{Tahap Pelaksanaan}

Pada pertemuan pertama kegiatan pembelajaran dilaksanakan pada hari kamis, 19 Oktober 2016 di kelas XI PS2, dengan 2 jam pelajaran ( 2 x 45 menit) mulai pukul 08.00 sampai dengan pukul 09.30.Kegiatan ini diawali dengan mengabsen kehadiran peserta didik. Ternyata peserta didik hadir semua.Langkah- langkah pembelajaran sebagai berikut :

1. Kegiatan awal

a. Apersepsi

1) Tanya jawab tentang pelajaran yang lalu

2) Menyampaikan pokok materi pembahasaan hari ini

3) Menginformasikan kompetensi dasar yang ingin dicapai dalam pembelajaran

4) Pembagian kelompok dan tugas masing-masing kelompok sebagai berikut:

a) Peserta didik di bagi dalam 6 kelompok, tiap kelompok kecil terdiri dari 5 orang karena jumlah peserta didik di kelas XI PS2 berjumlah 30 orang.

b) Guru menyampaikan tugas-tugas yang harus dikerjakan masingmasing anggota kelompok yang berbeda, tugas tersebut adalah:

- kelompok 1 ; metoda bimbingangan perorangan

- kelompok 2 ; sistimatika case studi

- kelompok 3 ; rencana dan pelaksanaan intervensi

- kelompok 4 ; kasus bolos sekolah 
- $\quad$ kelompok 5 ; relasi dalam kasus bolos sekolah

- kelompok 6 ; peranan pekerja sosial

\section{b.Kegiatan Akhir}

1) Guru pengajar mengklarifikasi ditiap kelompok bila terjadi esalahan konsep dan melakukan pelurusan konsep

2) Mengambil kesimpulan secara bersama-sama

3) Evaluasi hasil proses belajar mengajar.
Guru kolaborator terus mengawasi antusias dan aktivitas siswa selama proses pembelajaran berlangsung.

\section{Hasil Pengamatan}

Berdasarkan hasil pengamatan guru kolaborator, hasil proses pembelajaran metode pekerjaan sosial pada siklus 2 diperoleh informasi dengan data sebagai berikut :Hasil evaluasi siklus 2 dapat di lihat pada tabel 2 .

Tabel 2

Prestasi Hasil Belajar Metode Pekerjaan Sosial Siklus 2

\begin{tabular}{|c|c|c|c|c|c|}
\hline No & Katagori & Jumlah & Presentasi & Ketuntasan & Keterangan \\
\hline 1 & Sangat baik & 3 & $10 \%$ & \multirow{3}{*}{$\begin{array}{l}30 \text { orang } \\
\text { siswa yang } \\
\text { semua sudah } \\
\text { tuntas }\end{array}$} & $\begin{array}{l}\text { Sudah mencapai target } \\
\text { KKM yang ditentukan }\end{array}$ \\
\hline 2 & Baik & 22 & $73.33 \%$ & & \\
\hline 3 & Cukup & 5 & $16.66 \%$ & & \\
\hline 4 & Kurang & 0 & $0 \%$ & & \\
\hline 5 & $\begin{array}{l}\text { sangat } \\
\text { kurang }\end{array}$ & 0 & $0 \%$ & & \\
\hline & Jumlah & & siswa & & $99,99 \%$ \\
\hline
\end{tabular}


Berdasarkan hasil nilai tersebut ketuntasan belajar peserta didik dalam mata pelajaran Metode Pekerjaan Sosial telah mencapai kriteria ketuntasan minimal (KKM) yang telah ditentukan yaitu 75. Dengan nilai sangat baik dicapai oleh 3 peserta didik nilai yang dicapai yaitu 90, nilai baik diperoleh pada 22 peserta didik yang pencapaian nilainya yaitu 82 , sedang pencapaian nilai cukup yaitu 75 diperoleh 5 peserta didik.

\section{Refleksi}

Berdasarkan hasil pengamatan guru kolaborator, hasil proses pembelajaran Metode Pekerjaan Sosial pada silkus ke 2 diperoleh informasi dengan data sebagai berikut :

1. Kedisiplinan sebagian peserta didik mengikuti proses pembelajaran meningkat, keaktifannya. Sehingga nilai kedisiplinan peserta didik rata-rata $98 \%$.

2. Keaktifan peserta didik dalam mengikuti proses pembelajaran lebih antusias sehingga nilai ratarata $98 \%$.

3. Ketepatan waktu, peserta didik berusaha menyelesaikan pekerjaan, hasilnya rata-rata $97 \%$. Ini artinya kemampuan siswa untuk mengikuti pelajaran Metode Pekerjaan Sosial sudah meningkat.

4. Interaksi peserta didik dengan guru dan sesamanya, seperti bertanya kepada guru, bertanya kepada teman, menjawab pertanyaan, menaggapi, mengerjakan tugas hasilnya rata-rata 99\%. Kemudian disimpulkan bahwa pembelajaran Metode Pekerjaan Sosial dengan model pembelajaran pendekatan cooperatif learning mempercepat pemahaman peserta didik. Begitu pula dari hasil pengamatan guru kolaborator menunjukan respon dan kreatifitas peserta didik selama mengikuti belajar sangat baik. Hal ini karena guru dapat menciptakan suasana belajar yang menyenangkan.

5. Jadi disimpulkan bahwa materi pembelajaran Metode Pekerjaan Sosial dengan standar kompetensi case studi berhasil dengan baik dan memuaskan.

Dari pengalaman peneliti, menunjukkan bahwa hasil pembelajaran pada siklus 2 telah mencapai sesuai dengan KKM yang telah ditetukan.

Pemberian materi kesetiap kelompok pada siklus I membantu peserta didik untuk lebih cepat memahami. Peserta didik lebih aktif dan kreatif secara maksimal. Peserta didik termotivasi dalam mengerjakan tugas-tugas yang diberikan guru.

Suasana kelas lebih dinamis dan lebih efektif di pergunakan proses pembelajaran jika dibandingkan dengan sebelumnya.Berdasarkan hasil pengamatan telah tercapai hasil maksimal dalam proses pembelajaran Metode Pekerjaan Sosial pada siklus 2 diperoleh informasi dengan data sebagai berikut : 
1. Kedisiplinan sebagian peserta didik mengikuti proses pembelajaran masih kurang. Keaktifannya cenderung bermain main, sehingga nilai kedisiplinan peserta didik rata-rata $97 \%$.

2. Keaktifan peserta didik dalam mengikuti proses pembelajaran yang kecenderungannya main-main nilai rata-rata $98 \%$.

3. Ketepatan waktu peserta didik menyelesaikan pekerjaan hasilnya rata-rata 96\%. Ini artinya masih katagori cukup termotivasinya peserta didik.

4. Interaksi peserta didik dan guru dan sesamanya, seperti bertanya kepada guru, menjawab pertanyaan, menanggapi, mengerjakan tugas hasilnya ratarata $98 \%$.

Jadi disimpulkan bahwa materi pembelajaran Metode pekerjaan Sosial dengan standar kompetensi case studi kasus perorangan dapat dicapai dengan hasil yang sangat memuaskan, karena kriteria ketuntasan minimal (KKM) telah dicapai dengan baik.

\section{PEMBAHASAN}

Berdasarkan hasil yang diperoleh dari siklus 1 ke silus 2 menunjukan adanya perubahan peningkatan hasil belajar dengan penerapan model pembelajaran cooperative learning sebagai upaya meningkatkan hasil belajar Metode Pekerjaan Sosial peserta didik kelas XI PS2 SMKNegeri 28, cilandak. Jakarta Selatan.Hasil belajar tersebut dapat dilihat dari siklus I rata-rata $75 \%$ dan pada siklus 2 rata-rata 99\%, berarti terjadi peningkatan 24\%.Perubahan dan peningkatan hasil belajar diatas disimpulkan bahwa:

1. Telah menjawab rumusan masalah dalam penelitian tindakan kelas ini, yaitu apakah penerapan model pembelajaran cooperatif learning dapat meningkatkan hasil belajar Metode Pekerjaan sosial standar kompetensi case studi kasus perorangan kelas XI PS2 SMK Negeri 28, cilandak. Jakarta selatan

2. Tercapainya tujuan untuk menerapkan model pembelajaran cooperatif learning peserta didik kelas XI PS2 SMK Negeri 28, Cilandak. Jakarta selatan.

Hal ini menurut pengamatan kolaborator perubahan dan peningkatan hasil belajar disebabkan oleh beberapa faktor, yaitu:

a. Guru mampu menciptakan suasana belajar yang menyenangkan bagi peserta didiknya, serta menyajikan kegiatan belajar mengajar model cooperatif learning mendorong peserta didik untuk aktif meresponnya.

b. Proses pembelajaran dilaksanakan oleh peneliti memenuhi prosedur dan dilaksanakan konsisten sesuai dengan RPP.

c. Aktifitas peserta didik dalam mengikuti pembelajaran rata-rata mencapai $98 \%$.

d. Antusias serta kemauan belajar tampak optimal. Sehingga 
pengamat memberikan nilai ratarata $98 \%$.

e. Kedisiplinan dan ketepatan waktu dalam menyelesaikan tugas dari guru rata-rata $97 \%$.

f. Interaksi peserta didik dalam kegiatan pembelajaran sangat dinamis, seperti menjawab pertanyaan, mengajukan pertanyaan, mengerjakan tugas, sehingga oleh pengawas memperoleh nilai rata-rata $97 \%$.

Maka tidaklah berlebihan bila disimpulkan bahwa keberhasilan penelitian dalam penerapan model pembelajaran cooperatif learning sebagai upaya meningkatkan hasil belajar metode pekerjaan sosialpada peserta didik kelas XI PS2 SMK Negeri 28, Cilandak. Jakarta Selatan sangat memuaskan.

\section{KESIMPULAN}

Berdasarkan hasil penelitain tindakan kelas yang telah dilaksanakan disimpulkan bahwa :

1. Untuk meningkatkan hasil belajar metode pekerjaan sosial guru dapat menggunakan beberapa metode pembelajaran. Khusus untuk kelas XI model pembelajaran dengan pendekatan cooperatif learning. Artinya materi pelajaran yang disajikan hendaknya berorientasi kepada materi pelajaran didiskusikan oleh peserta didik .

2. Dalam proses pembelajaran agar peserta didik dapat berinteraksi dan kooperatif antar peserta didik, maka dibentuknya kelompok- kelompok kecil sangat cocok dengan perkembangan peserta didik kelas XI Sekolah menengah kejuruan.

3. Meningkatkan motivasi belajar, harga diri sikap dan perilaku yang positif, sehingga dengan pembelajaran kooperatif peserta didik akan tahu kedudukannya dan belajar untuk saling menghargai.

\section{Saran}

Bersadarkan kesimpulan yang sesuai dengan tujuan penelitian, di kemukakan saran-saran, antara lain :

1. Model pembelajaran dengan pendekatan cooperatif learning sangat cocok dipergunakan untuk peserta didik kelas XI Pekerjaan Sosial.

2. Suasana belajar yang menyenangkan perlu diterapkan, karena dapat mendorong atau memotivasi peserta didik untuk kreatif dalam belajar.

3. Metode belajar yang kooperatif dengan membentuk kelompokkelompok agar dilanjutkan.

4. Guru agar siap dan mau mengadakan penelitian tindakan kelas, sehingga mengetahui kelemahan dan kelebihan proses pembelajaran dengan metode yang dipergunakan agar hasil belajar dapat meningkat. 


\section{REFERENSI}

Harjomarsono, Boediman. 1990, Pemecahan Masalah dalam Bimbingan Sosial Perorangan, Sawangan Bogor

Purwanto, M Ngalim. 1987. Psikologi Pendidikan. Bandung: Remaja Karya

Soehoedi, Isman M, 1970, Sosial Case Work, Fakultas Kesejahteraan Sosial, Muhammadiyah, Jakarta

Syah, Muhibbin. 2003. Psikologi Belajar. Jakarta: PT Raya Grafindo Persada. 